\title{
Oecologia
}

\section{Wide outcrossing provides functional connectivity for new and old Banksia populations within a fragmented landscape \\ --Manuscript Draft--}

\begin{tabular}{|c|c|c|}
\hline Manuscript Number: & \multicolumn{2}{|l|}{ OECO-D-18-00588R3 } \\
\hline Full Title: & \multicolumn{2}{|c|}{$\begin{array}{l}\text { Wide outcrossing provides functional connectivity for new and old Banksia populations } \\
\text { within a fragmented landscape }\end{array}$} \\
\hline Corresponding Author: & \multicolumn{2}{|c|}{$\begin{array}{l}\text { Alison L Ritchie } \\
\text { School of Biological Sciences, University of Western Australia } \\
\text { Kings Park, WA AUSTRALIA }\end{array}$} \\
\hline \multirow[t]{4}{*}{ Order of Authors: } & \multicolumn{2}{|l|}{ Alison L Ritchie } \\
\hline & \multicolumn{2}{|l|}{ Rodney J Dyer } \\
\hline & \multicolumn{2}{|l|}{ Paul G Nevill } \\
\hline & \multicolumn{2}{|l|}{ Elizabeth A Sinclair } \\
\hline \multirow[t]{3}{*}{ Funding Information: } & $\begin{array}{l}\text { Australian Research Council } \\
\text { (LP100100620) }\end{array}$ & Dr Siegfried L Krauss \\
\hline & Holsworth Wildlife Research Endowment & Dr Alison L Ritchie \\
\hline & $\begin{array}{l}\text { Botanic Gardens and Parks Authority } \\
\text { (Kings Park Scholarship) }\end{array}$ & Dr Alison L Ritchie \\
\hline
\end{tabular}


Wide outcrossing provides functional connectivity for new and old Banksia populations within a fragmented landscape

Alison L. Ritchie (alison.ritchie@uwa.edu.au) $)^{1,2}$, Rodney J. Dyer (rjdyer@vcu.edu) ${ }^{3}$, Paul G. Nevill (paul.nevill@curtin.edu.au) ${ }^{1,4}$, Elizabeth A. Sinclair (esinclair@iinet.net.au) ${ }^{1,2}$ and Siegfried L. Krauss (Siegy.Krauss@dbca.wa.gov.au) $)^{1,2}$

${ }^{1}$ School of Biological Science, The University of Western Australia, Crawley, WA 6009, Australia.

${ }^{2}$ Kings Park Science, Department of Biodiversity, Conservation and Attractions, 2 Kattidj Close, Kings Park, WA 6005, Australia.

${ }^{3}$ Centre for Environmental Studies in Life Sciences, Virginia Commonwealth University, Richmond, VA, 23284, USA.

${ }^{4}$ now at Centre for Mine Site Restoration, School of Molecular and Life Sciences, Curtin University, Bentley, WA 6102, Australia.

\section{Address correspondence to:}

Alison Ritchie

School of Biological Sciences

The University of Western Australia

Crawley, WA 6009

Ph: +61894803691

Fax: +61893225064

E-mail: alison.ritchie@uwa.edu.au

Running Title: Reproductive functionality retained in fragmented Banksia woodlands. Article Type: Highlighted student research

This study is one of the first to examine plant functional connectivity, measuring effective pollen dispersal using new methods in landscape genetics. We found that new populations have integrated with old through long-distance pollination events. Retaining remnant populations in the urban matrix is vital for maintaining reproductive functionality at the landscape scale.

\section{Declaration of Authorship}

Author Contribution statement ALR, PGN, EAS and SLK conceived and designed the research. ALR performed the study and analysed the data. Popgraph analysis was performed by ALR and RJD. All authors contributed to writing the manuscript. 


\section{$1 \quad$ Abstract}

2 Habitat fragmentation affects landscape connectivity, the extent of which is influenced by the

3 movement capacity of the vectors of seed and pollen dispersal for plants. Negative impacts of

4 reduced connectivity can include reduced fecundity, increased inbreeding, genetic erosion

5 and decreased long-term viability. These are issues for not only old (remnant) populations,

6 but also new (restored) populations. We assessed reproductive and connective functionality

7 within and among remnant and restored populations of a common tree, Banksia menziesii

8 R.Br. (Proteaceae), in a fragmented urban landscape, utilizing a genetic and graph theoretical

9 approach. Adult trees and seed cohorts from five remnants and two restored populations were

10 genotyped using microsatellite markers. Genetic variation and pollen dispersal were assessed

11 using direct (paternity assignment) and indirect (pollination graphs and mating system

12 characterisation) methods. Restored populations had greater allelic diversity $(A r=8.08 ; 8.34)$

13 than remnant populations ( $A r$ range $=6.49-7.41)$. Genetic differentiation was greater

14 between restored and adjacent remnants $\left(F_{\mathrm{ST}}=0.03\right.$ and 0.10$)$ than all other pairwise

15 comparisons of remnant populations (mean $F_{\mathrm{ST}}=0.01 \pm 0.01 ; \mathrm{n}=16 P=0.001$ ). All

16 populations displayed low correlated paternity $\left(r_{p}=0.06-0.16\right)$ with wide-ranging realised

17 pollen dispersal distances $(<1.7 \mathrm{~km})$ and well-connected pollen networks. Here, we

18 demonstrate reproductive and connective functionality of old and new populations of $B$.

19 menziesii within a fragmented landscape. Due to long distance pollination events, the

20 physical size of these sites underestimates their effective population size. Thus, they are

21 functionally equivalent to large populations, integrated into a larger landscape matrix.

23 Keywords Banksia menziesii, restoration, mating system, pollinator services, popgraph. 
Introduction

25 Globally, one of the major processes threatening natural ecosystem function is anthropogenic landscape change (Eckert et al. 2010; Valiente-Banuet et al. 2015), which often results in increased spatial fragmentation and potential loss of native taxa (Tulloch et al. 2015). For plant populations, these changes alter the effectiveness of pollen and seed dispersal mechanisms (Lamont et al. 1993; Coates et al. 2007; Aizen et al. 2016). Alteration of dispersal vectors can lead to genetic isolation, increased drift and inbreeding, reductions in fitness, and potentially reproductive failure and local extinction (Cunningham 2000; Aguilar et al. 2006; Eckert et al. 2010; Vranckx et al. 2012). Ecological restoration has the potential to mitigate these pressures, by restoring biodiversity and recovering ecosystem services such as pollination and seed dispersal (Wortley et al. 2013; Perring et al. 2015). The practice of ecological restoration is extensive and growing worldwide, with major commitments that include reinstating 350 million hectares of forest by 2030 (Suding et al. 2015) and the landscape-scale restoration of highly fragmented systems (Menz et al. 2013). A key goal of ecological restoration is to re-establish self-sustaining ecosystems, ensuring that restored populations are able to persist in a dynamic setting in the short-term and have the capacity to undergo adaptive evolutionary change in the long term (Kettenring et al. 2014; Miller et al. 2017). Re-establishment of pollinator communities and genetic connectivity is critical for the long-term success of ecological restoration (Dixon 2009; Menz et al. 2011; Aavik and Helm 2017).

To date, ecological restoration focusing on plant dispersal vectors have documented a wide range of responses. For example, the response of insect communities have ranged from no recolonization (Forup and Memmott 2005) to complete recolonization of a restored habitat

47 (Forup et al. 2008). Bird pollinator communities have shown aggressive territorial behaviour 48 (Comer and Wooller 2002) and reduced community diversity (Munro et al. 2011). While 
these responses may be context specific, the overall goal of restoring pollination services must be to quantify standing patterns of genetic connectivity to an extent such that the robustness of ecological resilience can be estimated (Wortley et al. 2013: Proft et al. 2018).

The most common approach to quantifying genetic connectivity is through the application of hypervariable genetic markers (Kettenring et al. 2014; Williams et al. 2014; Mijangos et al. 2015; Krauss et al. 2017), which can address both localized as well as landscape level dispersal processes (e.g., Byrne et al. 2007, 2008; Krauss et al 2009; Ritchie and Krauss 2012; Aavik et al 2013). The spatial distribution of genetic varaition within existing populations and within single offspring cohorts can be used to gain both direct estimates (e.g., through paternity analysis; Marshall et al. 1998: Kalinowski et al. 2007) and indirect estimates (e.g., using pollination graphs, mating system analyses, and 2-generational approaches; Smouse et al. 2001; Ritland 2002; Dyer et al. 2012) of dispersal capacity and effectiveness. When applied across sampling locations, these approaches can further capture the extent to which local heterogeneity interacts with dispersal potential (Dyer 2015a).

In this study, we assessed reproductive and connective functionality within and among remnant and restored populations of Banksia menziesii (Proteaceae), a common, animalpollinated, self-incompatible tree native to Western Australia (Scott 1980). Banksia woodlands are becoming increasingly fragmented as the Perth metropolitan area of Western Australia continues to expand along the coastal corridor. Less than $28 \%$ of the original woodland area remains around Perth and as a consequence, Banksia woodlands were recently listed by the Australian government as an 'Endangered Ecological Community' under the $E P B C$ Act 1999 and therefore the species is a priority for ecological restoration (Stevens et al. 2016). Focusing on these fragmented and restored populations, we addressed the following questions: 
73 1. Are these restored (new) populations genetically depauperate and differentiated from the local natural (old) populations?

75 2. What is the extent of contemporary genetic connectivity via pollen dispersal among natural (old) urban remnants?

77 3. How do the mating patterns of B. menziesii vary across natural (old) urban remnants?

78 4. Has reproductive functionality, as measured by mating patterns and connectivity through pollen dispersal, been established in the restored (new) populations?

80

\section{$81 \quad$ Material and methods}

\section{Study system}

83 Banksia menziesii is a dominant tree or woody shrub species within these endangered woodlands which are distributed across the deep sandy soils of the Swan Coastal Plain of Western Australia (George and Gardner 1981; Corrick and Fuhrer 2002). The species is selfincompatible, with a long flowering season during the Austral autumn/winter (AprilSeptember). It is a major source of floral nectar for pollinating honeyeaters (Meliphagidae), bees (Ramsey 1988; Ramsey 1989) and the marsupial Honey Possum (Tarsipes rostratus) (Wooller and Woller 2013) during these months. The woody infructescences are weakly serotinous, with viable seeds being retained within the follicles (fruits) for ca. 9 months prior 91 to release following summer heat or fire (Lamont et al. 2007). Dispersal is predominantly by gravity, with almost all seeds falling within $10 \mathrm{~m}$ of the maternal plant, however, some longdistance dispersal can occur by wind-vortices and large parrots (Krauss et al. 2009). Finescale spatial genetic structure has been recorded up to $10 \mathrm{~m}$ within natural populations of Banksia (Krauss et al. 2009; Ritchie and Krauss 2012; Ritchie et al. 2017). Adult plants

96 within the natural populations are likely to be up to 300 years old, surviving in the landscape since well into the pre-European period (Lamont et al. 2007). 


\section{Study populations and sampling}

100 The study contrasted plants within restored (new) and three types of natural (old)

101 populations: restored populations (RS1 and RS2), fragmented remnant populations that were

102 adjacent to restored populations (AFR1 and AFR2), geographically fragmented remnant

103 populations (FR1 and FR2), and one large non-fragmented remnant (LR; Table 1; Fig. 1).

104 The two restorations were established in 1995 (RS1) and 1996 (RS2) following sand mining

105 by Rocla Quarry Products (now Hanson Construction Materials). Therefore, at the time of

106 sampling, restored trees were between 14 and 15 years old. A previous genetic study showed

107 RS1 was restored with locally sourced seed (Ritchie and Krauss 2012), while the source of

108 seed for RS2 is unknown. The two remnant woodlands (FR1 and FR2) became

109 geographically fragmented between 42 and 51 years ago by urban expansion.

\section{Reproductive attributes}

112 Ten maternal trees from each population were assessed for reproductive attributes by

113 quantifying the number of inflorescences produced, follicles (fruits) produced post flowering,

114 seed produced per follicle and mean seed mass. Generalised linear models (GLM) were

115 employed to determine differences in inflorescence count, follicle count (with Poisson error

116 distribution) viable seeds per follicle and proportion of viable seeds (with binomial logit

117 transformation) between populations and tested for normality of residuals using the Shapiro-

118 Wilk test and variation homogeneity using the Bartlett's test. Pearson's correlation coefficient

119 was calculated to determine any correlation between inflorescence count and follicle

120 production. Furthermore, we employed ANOVAs (function aov) to determine the effects of

121 population on seed mass (log-transformed). In significant models, we assessed differences

122 between population responses with Tukey's HSD post-hoc tests using the glht function 
within R multcomp package (Hothorn et al. 2008). All of the reproductive attribute data analyses were performed in the R statistical environment ( $\mathrm{R}$ Development Core Team).

DNA sampling, extraction and PCR amplification

127 Approximately 100 trees were sampled from each population within an approximate area of 200m x 200m. Leaf samples were collected from reproductively mature B. menziesii trees at all populations between December 2010 and January 2011. A minimum of ten seeds were

130 collected from multiple cones from the previous flowering season from each maternal tree

131 selected for reproductive attributes. The position of each tree was recorded using a Global

132 Positioning System (GPS). DNA was extracted from $0.8 \mathrm{~g}$ silica-dried leaf material using a

133 CTAB (cetyltrimethylammonium bromide) method (He et al. 2004; Doyle and Doyle 1990).

134 DNA was extracted from seeds using the extraction protocol of Jobes et al. (1995). Seed

135 coats were separated from the embryo to avoid contamination of DNA by maternal tissues,

136 then embryos were pulverized for 20 seconds in a FastPrep®-24 instrument (MP

137 Biomedicals, Inc., Solon, $\mathrm{OH})$. Microsatellite amplifications were performed for eleven 138 polymorphic markers; $B m \mathrm{~A} 1, B m \mathrm{~B} 6, B m \mathrm{~B} 102, B m \mathrm{~B} 106, B m \mathrm{C} 2, B m \mathrm{D} 1, B m \mathrm{D} 4, B m \mathrm{D} 103$ and

139 BmD105, previously designed for B. menziesii (Supplementary Table S1) and two, BaA3 and

$140 B a \mathrm{~B} 106$, previously designed for B. attenuata (He et al. 2004; He et al. 2007)

141 (Supplementary Table S1). Amplifications were performed with the following PCR

142 conditions: $96^{\circ} \mathrm{C}$ for 2 mins ( 1 cycle), followed by 30 cycles of $94^{\circ} \mathrm{C}$ for $1 \mathrm{~min}, 52$ to $57^{\circ} \mathrm{C}$

143 for $1 \mathrm{~min}$ (depending on the primer pair), $72^{\circ} \mathrm{C}$ for $1 \mathrm{~min}$ and final extension time of $72^{\circ} \mathrm{C}$ for

1447 mins. PCR products were separated by capillary electrophoresis and alleles scored using a

145 Beckman Coulter CEQ 8800 Genetic Analysis System (internal size standard SS400). 
147 Molecular data analysis

148 Genetic diversity within and among populations

149 Population genetic diversity measures were estimated for adult populations and offspring

150 (herein referred to as seed cohorts) using GenAlEx (version 6.502, Peakall and Smouse

151 2012). Genetic diversity estimates included the number of alleles ( $\mathrm{Na})$, effective number of

152 alleles $(\mathrm{Ne})$, frequency of private alleles $(\mathrm{Pr})$, expected and observed heterozygosity $(\mathrm{He}$ and

$153 \quad H o$ ) and fixation index (F). The program FSTAT (Goudet 2001) estimated allelic richness

$154(A r)$ and corrected for different samples sizes, allowing comparison among populations.

155 Significant differences between all parameter means were defined where $95 \%$ confidence

156 intervals did not overlap.

157 Pairwise population differentiation $\left(\mathrm{F}_{\mathrm{ST}}\right)$ was estimated among all pairs of adult remnant 158 populations, as well as between restored population and their adjacent remnant population using GenAlEx (Supplementary Table S2). Genetic structure of the restored populations

160 relative to all the other sampled populations was visualised using a Principal Component

161 Analysis (PCA) and performed using allele frequency data in gstudio 1.3 (Dyer 2015b) in R 162 version 3.2.4 (R Core Team 2016) (Supplementary Fig. S1).

163

164 Spatial genetic structure and connectivity

165 Adult genetic structure was analyzed using Population Graphs (Dyer \& Nason 2004), a

166 graph-theoretic analysis designed to quantify the spatial distribution of conditional genetic

167 covariance. Conditional covariance has been shown to capture underlying demographic

168 processes more precisely than methods based upon pairwise estimates of genetic structure

169 (such as those derived from F $_{\text {ST }}$ or its derivatives) or various genetic distance metrics (Dyer et

170 al. 2010). In the Population Graph, sample locations are represented as nodes within the

171 network, whose size is proportional to their within-population components of genetic 
172 covariance. Nodes are connected by edges, the presence of which are defined by conditional 173 genetic covariance (see Dyer 2015a for full description).

174 There are several benefits to this approach salient to this work. First, overall population

175 genetic structure is represented by the pattern of connectivity in the network itself

176 representing genetic covariance. Covariance is primarily created by both gene flow and

177 shared ancestry. If the nodes in the topology represent standing adult structure, then the connectivity represented is based upon a combination of historical and ongoing demographic processes. However, if the nodes are based upon pollen pools (e.g., the male genetic contribution to a half-sibling seed cohort, see Dyer \& Sork 2001) then reconstructed

181 connectivity is based upon contemporary gene flow. This allows a single analytical

182 framework to be used to examine processes generating genetic structure across a wide range 183 of temporal scales from a single reproductive event (Dyer et al. 2012) up to regional 184 estimates of phylogeographic history (Garrick et al. 2009; Baker \& Dyer 2011).

185 Finally, the distances between nodes in the network, based upon genetic covariance, can

186 be evaluated in relation to physical separation of nodes on the landscape under a model of 187 isolation by (graph) distance (IBGD; Dyer \& Nason 2004). If dispersal is uniform (e.g., the heterogeneity in the intervening habitat has no differential impact on connectivity) then the relative distances between nodes in Population Graph space should be proportional to

190 physical (Euclidean) separation. Parts of the network with deviations from these expectations

191 can identified when either the sample locales are further apart spatially than expected by

192 genetic covariance or sample locales are in closer proximity than expected by genetic

193 covariance. In the former case, this pattern is consistent with long-distance dispersal,

194 whereas the latter case represents a situation where intervening habitat is preventing direct 195 connectivity (see Dyer 2015a). 
196 For these analyses, both Population Graphs (from adult structure) and Pollination Graphs

197 (from pollen pool structure) were constructed using the R packages popgraph and gstudio

198 (Dyer 2015b, c). Topological analyses were performed using the igraph package (Csardi and

199 Nepusz 2006) in R. Specifics parameters measured were centrality (measures of node

200 location with the network) and betweenness (measures of information-theoretic flow through

201 the network).

202

203 Mating patterns, paternity assignment and contemporary gene flow

204 Mating system parameters were estimated for each population using the program MLTR version 3.4 (Ritland 2002) include maximum-likelihood single $\left(t_{s}\right)$ and multilocus $\left(t_{m}\right)$ outcrossing rates, bi-parental inbreeding $\left(t_{s}-t_{m}\right)$, correlated paternity $\left(r_{p}\right)$ and the effective number of pollen donors per family $\left(1 / r_{p}\right)$. Confidence intervals (CI at $\left.95 \%\right)$ were generated

208 for all estimates by bootstrap resampling 1,000 times.

209 Likelihood-based paternity analysis was conducted using the program CERVUS 3.0

210 (Marshall et al. 1998; Kalinowski et al. 2007). The simulation parameters used to assign

211 paternity to the most-likely individuals with a known level of statistical confidence were set

212 at 10,000 cycles of simulation, all trees were potential candidate parents (sampled

213 reproductive adults from within site or all sites, see Table 2) and 0.01 as the proportion of

214 loci mistyped (genotyping error rate). Confidence in assignments was measured as the

215 difference in critical logarithm of odds (LOD) scores between the candidate sire with the

216 highest score and the candidate sire with the second highest score under strict (95\%) and

217 relaxed $(80 \%)$ confidence levels. A LOD of $\leq 3.0$ indicates a father is 20 times more likely

218 than not to be the true father (Slate et al. 2000). Pollen dispersal distances (PDD) were

219 calculated from paternal assignments made under relaxed analysis conditions (80\% 
confidence) by using the GPS location of the maternal tree for a particular seed and the paternal tree identified as the most likely pollen donor.

Differentiation in maternal tree pollen pools $\left(\Phi_{F T}\right)$ and effective density $(d)$ across populations were estimated with TwoGener analysis using GenAlEx 6.502. Overall genetic differentiation between pollen pools $\left(\Phi_{F T}\right)$ and its variance was calculated following (Austerlitz and Smouse 2002) using known tree densities. Maternal trees sampling overlapping sets of pollen donors will have pollen pools with low among-mother genetic variance (e.g., $\left.\Phi_{F T}\right)$. Large estimates of pollen pool structure $\left(\Phi_{F T}\right)$ are consistent with reduction in pollen dispersal distance whereby maternal trees sample from increasingly differentiated pollen donor populations. The maximum pollen dispersal distance $(\delta)$, effective number of pollen donors per family $\left(N_{e p}=1 /\left(2 \Phi_{F T}\right)\right)$, and effective pollination neighbourhood area $\left(A_{e p=} N_{e p} / d(\mathrm{ha})\right)$, where $d$ is the density of reproductive plants, were also estimated (Austerlitz and Smouse 2001a, b).

Spatial differentiation of pollen pools was assessed to examine connectivity within and among populations by constructing Pollination Graphs (PG; Dyer and Nason 2004; Dyer et al. 2012) an extension of the Population Graph approach whereby the sampling location is based upon the pollen pool sampled by each maternal individual (estimated identically as is done for the TwoGener analysis) rather than adult structure. Pollination Graphs and their topological structure were analysed as described for Population Graphs above.

240 Results

\section{Reproductive attributes}

242 Inflorescence production was variable across populations being significantly higher in RS2

$243\left(\mathrm{RS} 2=21.7 \pm 0.8 ; \mathrm{GLM}, \chi^{2}=154.7, \mathrm{df}=6, P<0.001\right)$ in comparison to all populations

244 (range 5.9 - 10.4 inflorescences per tree, Table 1). Follicle production was correspondingly 
245 (Pearson's correlation coefficient $=0.52, P<0.001$ ) significantly different between

246 populations $\left(\mathrm{GLM}, \chi^{2}=653.7 \mathrm{df}=6, P<0.001\right)$, with adjacent population AFR1 and both

247 restored populations having the highest number of follicles (mean $=<50$ follicles per

248 maternal) in comparison to all other natural populations (mean $=>38$ follicles per maternal)

249 (Table 1). These patterns of higher inflorescence and follicles production however, did not

250 convert to higher numbers of viable seed produced per follicle, percentage of viable seed per

251 plant, or mean seed mass as they did not differ between populations (Table 1).

252

253 Diversity, Structure and Connectivity

254 Adult diversity and structure varied widely across sites (Fig. 2). Genetic diversity (He)

255 ranged from 0.53 (AFR1) up to 0.67 (RS1). Adult inbreeding was low overall but most

256 pronounced in populations FR1, FR2, \& RS2 with population RS1 showed the lowest level of

257 inbreeding of all populations. Populations RS1 and RS2 generally had higher levels of allelic

258 diversity ( $\mathrm{Na}$ and $\mathrm{Ar}$ ) and higher frequencies of private alleles (Pr) (Supplementary Fig. S1).

259 The Population Graph (Fig. 3) of adult locales was highly connected with populations LR,

260 AFR1, AFR2, and RS2 were the only ones without edges connecting all other sites. This

261 pattern suggests broadly covarying genetic structure among all locations.

262 The distribution of spatial and genetic structure in adult populations suggested restricted

263 historical gene flow under a model of isolation by graph distance (IBGD; Mantel Z=0.72, $P=$

264 0.003). Among individual populations, physical separation was greater than expected from

265 the genetic covariance (extended edges; a pattern consistent with long-distance dispersal) for 266 population pairs LR/RS2, FR/AFR1, and AFR1/AFR2 (Fig. 3). The potential for intervening

267 barriers to direct connectivity (edge compression) are also identified for connections between

268 RS1/FR1, RS1/FR2, and RS2/AFR2 (Fig. 3). 
The pattern of diversity within offspring cohorts was similar to that of adults (Fig. 2).

Heterozygosity was largest in RS1 and RS2. Overall allelic richness ( $\mathrm{Na}$ ) was most

were the most diverse, however, unlike the adult populations only RS2 showed increased frequency of rare alleles in the offspring pollen pool with RS1 having frequencies of rare alleles similar to the remaining locations.

We found significant, though low levels, of genetic structure among all adult remnant populations $\left(F_{S T \text { remnant }}=0.047, P=0.001\right)$. Both adult and seed cohorts showed significant differentiation from adjacent remnant populations, though RS1 was not as pronounced $\left(F_{S T \text {; }}\right.$ adults $=0.031, P=0.001$ vs. $\left.F_{S T ; \text { seed }}=0.029, P=0.001\right)$ as observed in RS2 $\left(F_{S T ; \text { adults }}=0.102\right.$, $P=0.001$ vs. $F_{S T ;}$ seed $\left.=0.036, P=0.001\right)$ suggesting some degree of isolation between restored and remnant populations. Across all pairs of populations, the restored site RS2 had the highest average structure (mean $\left.\mathrm{F}_{\mathrm{ST}}=0.093\right)($ Supplementary Table S2).

\section{Mating system, paternity assignment and contemporary gene flow}

284 Single and multilocus outcrossing rates were not significantly different from 1.0 and biparental inbreeding estimates were low for the restored populations and four of the five remnants (Table 2). The adjacent fragmented remnant 1 exhibited higher biparental inbreeding $\left(t_{\mathrm{m}}-t_{\mathrm{s}}\right.$ AFR1 $\left.=0.231\right)$. All estimates of correlated paternity were low $\left(r_{p}\right.$ range $=$ $0.06-0.16)$ and estimates of the effective number of pollen donors ranged from $6.3-16.4$ (Table 2). Differentiation among sampled pollen pools $\left(\Phi_{F T}\right)$ showed no significance between restored populations $\left(\mathrm{RS} 1: \Phi_{F T}=0.08 ; \mathrm{RS} 2: \Phi_{F T}=0.043, \Phi_{F T \text { remnants }}\right.$ mean $\left.=0.07 \pm 0.01\right)$ indicating similar pollen pool structure among populations. Estimates of effective number of

292 pollen donors were not significantly different between restored and natural populations (RS1:

293 MLTR $N_{e p}=7.9$, TwoGener $N_{e p}=6.2 ;$ RS2: MLTR $N_{e p}=16.4$, TwoGener $N_{e p}=11.9$; and 
294 MLTR $N_{e p \text {; remnants }}$ mean $=8.8 \pm 1.3$, TwoGener $N_{e p \text { remnants }}$ mean $=7.9 \pm 0.9$ ). The effective 295 neighbourhood area of the pollinators in RS1 and RS2 (14.7 $\mathrm{m}$ and $22.0 \mathrm{~m}$ radius around 296 maternal trees, respectively; $A_{e p \text { restored }}=0.07$ ha and 0.15 ha) was lower than the average for 297 natural populations $\left(24.5 \mathrm{~m} \pm 5.8\right.$ radius; $\left.A_{e p \text { remnants mean }}=0.23 \mathrm{ha} \pm 0.10\right)$. From pollen pool 298 structure, the TwoGener analysis suggest that restored populations had shorter pollen 299 dispersal distance estimates $\left(\delta_{\text {restored }}=9.2 \mathrm{~m}\right.$ and $\left.13.6 \mathrm{~m}\right)$ in comparison to the natural 300 populations $\left(\delta_{\text {remnants }}\right.$ mean $=27.9 \mathrm{~m} \pm 10.9$; Table 2$)$.

301 While the TwoGener analysis documents the magnitude of genetic structure in sampled 302 pollen pools (via $\Phi_{F T}$ ), Pollination Graphs depict how covariation is spatially distributed 303 across the landscape. Edges among maternal locations indicate significant genetic covariance

304 between sampled pollen pools (Fig. 4). In general, the amount of edge connectivity (e.g., the 305 fraction of potential edges in the network) was greatest in LR (Fig. 4a; $p=0.27$ ), roughly half 306 as much for the FR1/FR2 and AFR1/RS1 sites (Fig. 4b \& Fig. 4c; $p=0.13$ each), and lowest in the AFR2/RS2 (Fig. 4d; $p=0.08$ ). For locations with dual sampling sites, the FR1/FR2 complex had the highest amount of among-fragment connectivity (23\% of the edges connect nodes between fragmented sites; Fig. 4b) across the urban matrix. Both AFR/RS sites (Fig.

$3104 \mathrm{c} \& 4 \mathrm{~d})$ had lower inter-site connectivity (11\% for AFR1/RS1 and 13\% for AFR2/RS2 311 respectively), however do indicate some degree of restored site integration. Not all sites had completely connected components, FR1/FR2 had three isolated nodes (e.g., no connections

313 whatsoever) and the AFR2/RS2 locale has several disconnected subgraphs. Disconnected

314 pollen pools suggest independence in the set of pollen donors are contributing to maternal 315 individuals, for which we have not captured

316 Direct analysis of paternity in these populations yielded low assignment likelihoods $(<5 \%$ 317 of 681 seed, restored $=9$ seed, $4.5 \%$; natural $=28$ seed, $5.8 \%)$ as critical LOD scores were 318 high, 8.04 for $95 \%$ and 6.24 for $80 \%$. Sampled plants were excluded as sires for 55 (8\%) 
seeds, from which we inferred these to be the product of long-distance dispersal of pollen, from beyond the local population. Fragmented populations had greater maximum pollen dispersal distances than restored populations (CERVUS: PDD remnants mean $=614.8 \mathrm{~m}$; PDD restored mean $=185.5 \mathrm{~m})($ Table 2$)$. The pollen dispersal distance estimates from assignments (CERVUS) ranged from $4.0 \mathrm{~m}$ to $1.7 \mathrm{~km}$, with a mean and median of $391.0 \mathrm{~m}$ and $146.4 \mathrm{~m}$.

\section{Discussion}

326 Habitat fragmentation may result in fewer and potentially more isolated plant populations

327 with reduced dispersal at local, landscape and regional scales predicted (Young and Clarke 328 2000). The exchange of pollen offers a way by which genes can be moved between these remnant patches, mitigating potential negative genetic impacts and ensuring plant functional connectivity (Kramer et al. 2008; Auffret et al. 2017). For remnant (old) and restored (new) populations this requires that individuals not only survive to produce viable seed (following effective pollen dispersal) but result in the establishment and survival of a new adult plant for genetic integration.

Our assessment of functional connectivity across new and old populations of Banksia menziesii within a highly fragmented urban landscape has shown that seed of both remnant and restored populations retain high genetic diversity through wide outcrossing. We found no evidence to suggest habitat fragmentation and the associated spatial isolation of natural remnants or restored $B$. menziesii populations is a barrier to pollinator movement into and among remnants within an urban landscape at present. All study populations were equally fecund (once adjusted for flowering), similarly genetically diverse, completely outcrossed, with low correlated paternity, multiple shared paternal assignments, and wide genetic connectivity. Natural remnant populations adjacent to restored populations were shown to provide trans-boundary pollinator services, indicating a vital role in establishing reproductive 
344 functionality. Genetic covariance among populations displayed in the popgraph network analysis confirms extensive historical genetic connectivity. There are (unmeasured) and likely were (historically) intermediary remnants facilitating gene flow between populations and it is also likely that these populations are not yet on their own evolutionary trajectories. population size estimates $(\mathrm{Ne})$ in this study, which is likely due to a combination of large effective population size and time since fragmentation (42-51 years) for these long-lived trees. Longevity of these slow maturing trees (many may be decades old) provides the capacity for populations to withstand short-term physical fragmentation effects (Vranckx et al. 2012), and therefore have some resilience as long as pollinators are present (Breed et al. 2015).

\section{Connectivity among old remnant populations}

This study complements others (Coates et al. 2007; Krauss et al. 2009; Ritchie and Krauss 2012; Krauss et al. 2013; Frick et al. 2014; Ritchie et al. 2017) to show that banksias typically contain high allelic diversity, low levels of population genetic differentiation, and a capacity for long-distance pollen dispersal due to their highly mobile nectarivorous honeyeater bird pollinators. For plant species that depend on biotic pollination to produce seeds, functional connectivity depends to a large extent on the type of pollinator, their behaviour and how their movement is influenced by landscape factors (Auffret et al. 2017).

364 Some honeyeaters, such as Western Spinebills (Acanthorhynchus superciliosus) have a

365 recorded home range of $0.2-0.5$ ha within nature reserves (Newland and Wooller 1985), whereas Red Wattlebirds (Anthochaera carunculata) and Singing Honeyeaters (Gavicalis virescens) do well in the urban environment (Davis et al. 2013) and can fly much larger 
369 differences in the topologies of our Pollination Graph networks. These pollinators may use

370 intermediate remnants, road verges or urban gardens to forage, helping maintain connectivity across fragmented urban landscapes (Shanahan et al. 2011). Our results suggest that they can effectively transfer pollen grains at least $1.7 \mathrm{~km}$ between fragments.

\section{Connectivity of new restored populations and the importance of remnant vegetation}

Successful recruitment, maintenance and survival of restored populations is influenced by the surrounding landscape (Aavik and Helm 2017; Proft et al. 2018), and our study demonstrates the role that natural adjacent remnants play in delivering trans-boundary pollinator services to restored populations. The increased allelic richness, reduced differentiation between the adult and restored seed cohorts $\left(F_{\mathrm{ST}}\right)$, and paternity assignments confirms high genetic exchange between restored and adjacent natural B. menziesii populations even though restored populations displayed shorter pollen dispersal distance estimates. These shorter distances in comparison to natural populations was likely due to the significantly higher inflorescence production in the restored populations leading to higher pollinator attraction and higher follicle production. However, these pollination events and follicle production did not result in higher seed production, most likely due to a combination of resource allocation by the plant and geitonogamy of a self-incompatible species with prezygotic and/or postzygotic mechanisms stopping the production of selfed seed.

Pollen pool structure analysis in this study showed low to comparable levels of differentiation among pollen pool families and high number of effective pollen donors, similar to that of the large non-fragmented remnant. This implies a high level of gene flow between these restored and remnant adjacent populations and successful integration of restored plants has been achieved.

Adjacent land use has been proven to play a key role in the maintenance of genetic 
394 diversity of habitats (Aavik et al. 2013; Helsen et al. 2013). A recent study by Crouzeilles and

395 Curran (2016) showed that restoration success of forests, assessed through changes in species

396 diversity, was directly associated with undisturbed forest cover within a $10 \mathrm{~km}$ radius.

397 Conservation actions have largely focused on retaining large fragmented patches,

398 disregarding the increasingly crucial role that smaller remnant patches play in the

399 conservation and community persistence of remaining and restored vegetation (Tulloch et al.

400 2015).

401

\section{Genetic integration}

403 Higher genetic diversity (allelic richness and frequency of private alleles) was found in

404 restored populations compared to remnant populations. The degree of genetic differentiation

405 among adults of the (new) restored populations was 3.5 times greater in magnitude than those at (old) remnant populations, indicating a mixed provenance seed source was used. The

Population network also supports this conclusion, displaying compressed edges due to higher than expected genetic diversity in the restored population with respect to distance, between all the populations sampled. The genetic structure within restored populations differed due to the random mixing and sowing of seed, rather than limited natural dispersal (Krauss et al.

411 2009; Ritchie and Krauss 2012; Ritchie et al. 2017) by gravity and thus specifically, the gene

412 pool and effective pollination neighbourhood area of Restored Site 2 was greater than in the 413 natural remnant populations sampled.

414 The introduction and mixing of non-local alleles with a local gene pool could be beneficial 415 (heterosis), detrimental (outbreeding depression) or neutral (McKay et al. 2005), depending 416 on the level of inbreeding and the length of time gene pools have been isolated (Frankham et 417 al. 2011). Experimental outcrossing by hand of B. ilicifolia flowers on plants separated by 30 $418 \mathrm{~km}$ led to heterosis, expressed as improved germination of seed and early growth of seedlings 
compared to local crosses (Heliyanto et al. 2006). A similar result may be expected in $B$. menziesii and suggests that wide outcrossing stemming from the introduction of non-local provenance genotypes may be beneficial in highly outcrossed banksias, but does require further investigation. These restoration sites offer unique opportunities for on-going assessment, through a facilitation of wide outcrossing between co-occurring plants by hand pollination.

\section{Conclusions}

427 Despite the recognized importance of pollination and functional connectivity in restoration 428 (Dixon 2009; Menz et al. 2011), few studies have addressed these issues (Thomas et al. 2014; 429 Aavik and Helm 2017; Proft et al. 2018). Recent methodological advances in landscape 430 genetics provides powerful new tools for assessing the impacts of landscape change through the ecological functioning of old and new populations (Hufford and Mazer 2003; Williams et al. 2014; Mijangos et al. 2015; Proft et al. 2018) of longer-lived species that have now matured to reproductive age. We have demonstrated a capacity for reproductive functionality in new B. menziesii populations that is only possible through functional connectivity within and among remnant and restored populations, as a consequence of highly mobile bird pollinators.

437 Landscape genetics and functional connectivity needs to be taken into account for ensuring the long-term survival of old and new populations, with consideration of how populations are integrated into the larger ecological matrix (Elliott et al. 2012; Aavik and

440 Helm 2017). Most (87.5\%) flowering plant species are dependent on animals for pollination

441 (Ollerton et al. 2011). Plant functional connectivity therefore can change, not only as a result

442 of a landscape modification but also with changes in the type, characteristics, behaviour,

443 diversity or abundance of pollinators, or the plants' ability to use these pollinator services 
444 (Auffret et al. 2017). Conservation and restoration of pollinator services and functional

445 connectivity requires a consideration of all stages of the dispersal process with the presence,

446 community (multiple pollinator species) and movement of pollinators in the broader

447 landscape (Aguilar et al. 2006; Menz et al. 2011). Conservation of remnants irrespective of

448 their size needs consideration, especially in this threatened ecological system as they are

449 shown to contain high genetic diversity, and display differing mating system metrics. The

450 distances at which inter-patch connectivity dissolves for different pollination syndromes

451 needs to be identified (Aizen et al. 2016) for the benefit of conservation and restoration

452 success.

453

454 Acknowledgements Thanks to Janet Anthony for assistance with the genetic work undertaken in the laboratory and Carole Elliott and Bryn Funnekotter for providing comments and helpful suggestions for improving the paper. This work was supported by

Rocla Quarry Products (now Hanson Construction Materials), a Holsworth Wildlife Research

Endowment and a Friends of Kings Park writing scholarship to ALR, the Botanic Gardens and Parks Authority and a linkage grant to SLK from the Australian Research Council

460 (LP100100620). ALR was supported by an Australian Postgraduate Award during this study. 461

462 Conflict of Interest The authors declare that they have no conflict of interest.

\section{References}

465 Aizen MA, Gleiser G, Sabatino M, Gilarranz LJ, Bascompte J, Verdú M (2016) The

466 phylogenetic structure of plant-pollinator networks increases with habitat size and isolation. Ecol Lett 19:29-36 doi:10.1111/ele.12539 
Auffret AG, Rico Y, Bullock JM et al. (2017) Plant functional connectivity - integrating landscape sructure and effective dispersal. J Ecol 105:1648-1656 doi:10.1111/13652745.12742

Aguilar R, Ashworth L, Galetto L, Aizen MA (2006) Plant reproductive susceptibility to habitat fragmentation: review and synthesis through meta-analysis. Ecol Lett 9:968980 doi: doi:10.1111/j.1461-0248.2006.00927.x

Austerlitz F, Smouse PE (2001a) Two-generation analysis of pollen flow across a landscape III. Impact of adult population structure. Genet Res Camb 78:271-280 doi: doi:10.1017/S0016672301005341

Austerlitz F, Smouse PE (2001b) Two-generation analysis of pollen flow across a landscape. II. Relation between $\Phi f t$, pollen dispersal and interfemale distance. Genetics 157: $851-857$

Austerlitz F, Smouse PE (2002) Two-generation analysis of pollen flow across a landscape. IV. Estimating the dispersal parameter. Genetics 161: 355-363

Aavik T, Holderegger R, Edwards PJ, Billeter R (2013) Patterns of contemporary gene flow suggest low functional connectivity of grasslands in a fragmented agricultural landscape. J Appl Ecol 50:395-403 doi: 10.1111/1365-2664.12053

Aavik T, Helm A (2017) Restoration of plant species and genetic diversity depends on landscape-scale dispersal. Restor Ecol doi:10.1111/rec.12634

Baker SA, Dyer RJ (2011) Invasion genetics of Microstegium vimineum (Poaceae) within the James River Basin of Virginia, USA. Cons Gen 12:793-803 doi: 10.1007/s10592-0110186-0

Breed MF, Ottewell KM, Gardner MG, Marklund MH, Stead MG, Harris JB, Lowe AJ (2015) Mating system and early viability resistance to habitat fragmentation in a birdpollinated eucalypt. Heredity 115:100-107 doi: 10.1038/hdy.2012.72 
493 Byrne M, Elliott C, Yates C, Coates D (2007) Extensive pollen dispersal in a bird-pollinated

494

495

496

497

498

499

500

501

502

503

504

505

506

507

508

509

510

511

512

513

514

515

516

517 shrub, Calothamnus quadrifidus, in a fragmented landscape. Mol Ecol 16:1303-1314 doi: 10.1111/j.1365-294X.2006.03204.x

Byrne M, Elliott CP, Yates CJ, Coates DJ (2008) Maintenance of high pollen dispersal in Eucalyptus wandoo, a dominant tree of the fragmented agricultural region in Western Australia. Conserv Genet 9:97-105 doi: 10.1007/s10592-007-9311-5

Coates DJ, Sampson JF, Yates CJ (2007) Plant mating systems and assessing population persistence in fragmented landscapes. Aust J Bot 55:239 doi: 10.1071/BT06142

Comer SJ, Wooller RD (2002) A comparison of the passerine avifaunas of rehabilitated minesite and nearby reserve in south-western Australia. Emu 102:305-311 doi: 10.1071/MU00042

Corrick MG, Fuhrer BA (2002) Wildflowers of Western Australia. The Five Miles Press Pty Ltd. Nobel Park, Victoria.

Crouzeilles R, Curran M (2016) Which landscape size best predicts the influence of forest cover on restoration success? A global meta-analysis on the scale of effect. J Appl Ecol 53:440-448 doi: 10.1111/1365-2664.12590

Csardi G, Nepusz T (2006) The igraph software package for complex network research, InterJournal, Complex Systems 1695

Cunningham SA (2000) Depressed pollination in habitat fragments causes low fruit set. Proc R Soc Lond B 267:1149-1152 doi: 10.1098/rspb.2000.1121

Davis RA, Wilcox J (2013) Adapting to suburbia: bird ecology on an urban-bushland interface in Perth, Western Australia. Pac Conserv Biol 19:110-120 doi: 10.1071/PC130110

Davis RA, Gole C, Roberts JD (2013) Impacts of urbanisation on the native avifauna of Perth, Western Australia. Urban Ecosys 16:427-452 doi: 10.1007/s11252-012-0275-y 
518 Dixon KW (2009) Pollination and restoration. Science 325:571-573 doi: 10.1126/science. 1176295

Doyle JJ, Doyle JL (1990) Isolation of plant DNA from fresh tissue. Focus 12:13

Dyer RJ, Sork VL (2001) Pollen Pool Heterogeneity in Shortleaf Pine, Pinus echinata Mill. Mol Ecol 10: 859-866 doi: 10.1046/j.1365-294X.2001.01251.X

Dyer RJ, Nason JD (2004) Population Graphs: the graph theoretic shape of genetic structure. Mol Ecol 13: 1713-27 doi: 10.1111/j.1365-294X.2004.02177.x

Dyer RJ, Chan DM, Gardiakos VA, Meadows CA (2012) Pollination graphs: quantifying 27:239-251 doi: 10.1007/s10980-011-9696-X

Dyer RJ, Nason JD, Garrick RC (2010) Landscape modeling of gene flow: Improved power using conditional genetic distance derived from the topology of population networks. Mol Ecol 19:3746-3759 doi: 10.1111/j.1365-294X.2010.04748.x

Dyer RJ (2015a) Population graphs and landscape genetics. Annu Rev Ecol Evol Syst 46:327-342 doi: 10.1146/annurev-ecolsys-112414-054150

Dyer RJ (2015b) Package 'gstudio': analyses and functions related to the spatial analysis of genetic marker data [R package]

Dyer RJ (2015c) Package 'popgraph': an R package that constructs and manipulates population graphs [R package]

Eckert CG, Kalisz S, Geber MA et al (2010) Plant mating systems in a changing world. Trends Ecol Evol 25:35-43 doi: 10.1016/j.tree.2009.06.013

Elliott C, Lindenmayer D, Cunningham S, Young A (2012) Landscape context affects honeyeater communities and their foraging behaviour in Australia: implications for plant pollination. Lands Ecol 27:393-404 doi: 10.1007/s10980-011-9697-9 
543 Forup ML, Memmott J (2005) The restoration of plant-pollinator interactions in hay meadows. Restor Ecol 13:265-274 doi: 10.1111/j.1526-100X.2005.00034.x

Forup ML, Henson KSE, Craze PG, Memmott J (2008) The restoration of ecological interactions: plant-pollinator networks on ancient and restored heathlands. J Appl Ecol 45:742-752 doi: 10.1111/j.1365-2664.2007.01390.x

Frankham R, Ballou JD, Eldridge MDB, et al (2011) Predicting the probability of outbreeding depression. Conserv Biol 25:465-475 doi: 10.1111/j.15231739.2011.01662.x

Frick KM, Ritchie AL, Krauss SL (2014) Field of dreams: restitution of pollinator services in restored bird-pollinated plant populations. Restor Ecol 22:832-840 doi: $10.1111 /$ rec. 12152

Garrick RC, Nason JD, Meadows CA, Dyer RJ (2009) Not just vicariance: phylogeography of a Sonoran desert euphorb indicates a major role of range expansion along the Baja peninsula. Mol Ecol 18: 1916-1931 doi: 10.1111/j.1365-294X.2009.04148.x

George AS, Gardner C (1981) Banksia book. Kangaroo Press in association with the Society for Growing Australian Plants, NSW

Goudet J (2001) FSTAT, a program to estimate and test gene diversities and fixation indices. v2.9.3. Lausanne University, Lausanne, Switzerland

He T, Krauss SL, Lamont BB, Miller BP, Enright NJ (2004) Long-distance seed dispersal in attenuata (Proteaceae). Mol Ecol Notes 7:1329-1331 doi: 10.1111/j.14718286.2007.01871.x 
Heliyanto B, Krauss SL, Lambers H, Cawthray GR, Veneklaas EJ (2006) Increased ecological amplitude through heterosis following wide outcrossing in Banksia ilicifolia R.Br. (Proteaceae). J Evol Biol 19:1327-1338 doi: 10.1111/j.14209101.2005.01067.x

Helsen K, Jacquemyn H, Hermy M, Vandepitte K, Honnay O (2013) Rapid buildup of genetic diversity in founder populations of the Gynodioecious plant species Origanum vulgare after semi-natural grassland restoration. PLoS One 8:e67255 doi: 10.1371/journal.pone.0067255

Hothorn T, Bretz F, Westfall P (2008) Simultaneous inference in general parametric models. Biometric J 50: 346-363 doi: 10.1002/bimj.200810425

Hufford KM, Mazer SJ (2003) Plant ecotypes: genetic differentiation in the age of ecological restoration. Trends Ecol Evol 18:147-155 doi: 10.1016/S0169-5347(03)00002-8

Jobes DV, Hurley DL, Thien LB (1995) Plant DNA isolation: a method to efficiently remove polyphenolics, polysaccharides, and RNA. Taxon 379-386 doi: 10.2307/1223408

Kalinowski ST, Taper ML, Marshall TC (2007) Revising how the computer program CERVUS accommodates genotyping error increases success in paternity assignment. Mol Ecol Notes 16:1099-106 doi: 10.1111/j.1365-294X.2007.03089.x

Kettenring KM, Mercer KL, Reinhardt Adams C, Hines J (2014) Application of genetic diversity-ecosystem function research to ecological restoration. J Appl Ecol 51:339348 doi: $10.1111 / 1365-2664.12202$

Kramer AT, Ison JL, Ashley MV, Howe HF (2008) The paradox of forest fragmentation genetics. Conserv Biol 22:878-885 doi: 10.1111/j.1523-1739.2008.00944.x

Krauss SL, He T, Barrett LG, Lamont BB, Enright NJ, Miller BP, Hanley ME (2009) Contrasting impacts of pollen and seed dispersal on spatial genetic structure in the bird-pollinated Banksia hookeriana. Heredity 102:274-85 doi: 10.1038/hdy.2008.118 
593 Krauss SL, Sinclair EA, Bussell JD, Hobbs RJ (2013) An ecological genetic delineation of local seed-source provenance for ecological restoration. Ecol Evol 3:2138-2149 doi: 10.1002/ece3.595

Krauss SL, Phillips RD, Karron JD, Johnson SD, Roberts, DG, Hopper SD (2017) Novel consequences of bird pollination for plant mating. Trends Plant Sci 2:395-410 doi: 10.1016/j.tplants.2017.03.005

Lamont BB, Klinkhamer PGL, Witkowski ETF (1993) Population fragmentation may reduce fertility to zero in Banksia goodii - a demonstration of the Allee effect. Oecologia 94:446-450 doi: 10.1007/BF00317122

602

Lamont BB, Enright NJ, Witkowski ETF, Groeneveld J (2007) Conservation biology of banksias: insights from natural history to simulation modelling. Aust J Bot 55:280292 doi: 10.1071/BT06024

605

Marshall TC, Slate J, Kruuk LEB, Pemberton JM (1998) Statistical confidence for likelihood606 based paternity inference in natural populations. Mol Ecol 7:639-655 doi:

McKay JK, Christian CE, Harrison S, Rice KJ (2005) “How local is local?”-A review of 609 practical and conceptual issues in the genetics of restoration. Restor Ecol 13:432-440 doi: 10.1111/j.1526-100X.2005.00058.x

Menz MH, Phillips RD, Winfree R, Kremen C, Aizen MA, Johnson SD, Dixon KW (2011) Reconnecting plants and pollinators: challenges in the restoration of pollination

614 Menz MH, Dixon KW, Hobbs RJ (2013) Hurdles and opportunites for landscape-scale 615 restoration. Science 339:526-527 doi: 10.1126/science.1228334 
618 Miller BP et al (2017) A framework for the practical science necessary to restore sustainable, 619 resilient, and biodiverse ecosystems. Restor Ecol 25:605-617 doi: 10.1111/rec.12475

620 Munro NT, Fischer J, Barrett G, Wood J, Leavesley A, Lindenmayer DB (2011) Bird's response to revegetation of different structure and floristics - are "restoration plantings" restoring bird communities? Restor Ecol 19:223-235 doi: 10.1111/j.1526-

Newland CE, Wooller RD (1985) Seasonal changes in a honeyeater assemblage in Banksia woodland near Perth, Western Australia. N.Z. J Zool 12:631-636 doi: $10.1080 / 03014223.1985 .10428312$

Ollerton J, Winfree R, Tarrant S (2011) How many flowering plants are pollinated by animals? Oikos 120:321-326 doi: 10.1111/j.1600-0706.2010.18644.x

Peakall R, Smouse PE (2012) GenAlEx 6.5: genetic analysis in Excel. Population genetic software for teaching and research—an update. Bioinformatics 28:2537-2539 doi: 10.1093/bioinformatics/bts460

Perring MP, Standish RJ, Price JN, Craig MD, Erickson TE, Ruthrof KX, Whiteley AS, Valentine LE, Hobbs RJ (2015) Advances in restoration ecology: rising to the challenges of the coming decades. Ecosphere 6:1-25 doi: 10.1890/ES15-00121.1

Proft KM, Jones ME, Johnson CN, Burridge CP (2018) Making the connection: expanding the role of restoration genetics in restoring and evaluating connectivity. Restor Ecol doi: $10.1111 /$ rec. 12692

639

640

R Core Team (2016) R: a language and environment for statistical computing. R Foundation

Ramsay MW (1988) Differences in pollinator effectiveness of birds and insects visiting Banksia menziesii (Proteaceae). Oecologia 76:119-124 doi: 10.1007/BF00379609 
643 Ramsay MW (1989) The seasonal abundance and foraging behaviour of honeyeaters and their potential role in the pollination of Banksia menziesii. Aust J Ecol 14:33-40 doi: 10.1111/j.1442-9993.1989.tb01006.x

Ritchie AL, Krauss SL (2012) A genetic assessment of ecological restoration success in Banksia attenuata. Restor Ecol 20:441-449 doi: 10.1111/j.1526-100X.2011.00791.x

Ritchie A, Nevill PG, Sinclair EA, Krauss SL (2017) Does restored plant diversity play a role in the reproductive functionality of Banksia populations? Restor Ecol 25:414-423 doi: $10.1111 /$ rec. 12456

Ritland K (2002) Extensions of models for the estimation of mating systems using $n$ independent loci. Heredity 88:221-228 doi: 10.1038/sj.hdy.6800029

Scott JK (1980) Estimation of the outcrossing rate for Banksia attenuata R.Br. and Banksia menziesii R.Br. (Proteaceae). Aust J Bot 28:53-59 doi: 10.1071/BT9800053

Shanahan DF, Miller C, HP Possingham HP, Fuller RA (2011) The influence of patch area and connectivity on avian comunities in urban revegetation. Biol Cons 144:722-729 doi: 10.1016/j.biocon.2010.10.014

Slate J, Marshall T, Pemberton J (2000) A retrospective assessmnet of the accuracy of the paternity inference program CERVUS. Mol Ecol 9:801-808 doi: 10.1046/j.1365294x.2000.00930.x

Smouse PE, Dyer RJ, Westfall RD, Sork VL (2001) Two-generation analysis of pollen flow 665

Stevens JC, Rokich DP, Newton VJ, Barrett RL, Dixon KW (2016) Banksia woodlands: A restoration guide for the Swan Coastal Plain. UWA Press, Western Australia.

666 Suding K et al (2015) Committing to ecological restoration. Science 348:638-640 doi:

667 10.1126/science.aaa4216 
668 Thomas E, Jalonen R, Loo J, Boshier D, Gallo L, Cavers S, Bordács S, Smith P, Bozzano M

669

670

671

672

673

674

675

676

677

678

679

680

681

682

683

684

685

686 (2014) Genetic considerations in ecosystem restoration using native tree species. For Ecol Manage 333:66-75 doi: 10.1016/j.foreco.2014.07.015Tulloch AIT, Barnes MD, Ringma J, Fuller RA, Watson JEM (2015) Understanding the importance of small patches of habitat for conservation. J Appl Ecol 53:418-429 doi: 10.1111/13652664.12547

Valiente-Banuet A et al (2015) Beyond species loss: the extinction of ecological interactions in a changing world. Funct Ecol 29:299-307 doi: 10.1111/1365-2435.12356

Vranckx G, Jacquemyn H, Muys B, Honnay O (2012) Meta-analysis of susceptibility of woody plants to loss of genetic diversity through habitat fragmentation. Conserv Biol 26:228-237 doi: 10.1111/j.1523-1739.2011.01778.x

Williams AV, Nevill PG, Krauss SL (2014) Next generation restoration genetics: applications and opportunities. Trends Plant Sci 19:529-537 doi: 10.1016/j.tplants.2014.03.011

Wooller R, Wooller SJ (2013) Sugar and Sand: The world of the Honey Possum. Swanbrae Press, Cottesloe, Western Australia

Wortley L, Hero J-M, Howes M (2013) Evaluating ecological restoration success: A review of the literature. Rest Ecol 21:537-543 doi: 10.1111/rec.12028

Young AG, Clarke GM (eds) (2000) Genetics, demography and viability of fragmented populations. Cambridge University Press. 
687 Table 1 Mean values ( $\pm 1 \mathrm{SE}$ ) for reproductive attributes (inflorescences, follicles and seeds) of 10 trees within five remnants (old) and two

688 restored (new) populations of Banksia menziesii. Different row subscripts indicate significant differences between those populations.

\begin{tabular}{|c|c|c|c|c|c|c|c|c|}
\hline \multirow[b]{2}{*}{ Population } & \multirow{2}{*}{$\begin{array}{l}\begin{array}{c}\text { Non- } \\
\text { fragmented }\end{array} \\
\text { Large remnant } \\
\text { (LR) }\end{array}$} & \multicolumn{2}{|c|}{ Fragmented } & \multicolumn{2}{|c|}{ Adjacent } & \multicolumn{2}{|c|}{ Restored } & \multirow[b]{3}{*}{$P$-value } \\
\hline & & $\begin{array}{l}\text { Fragmented } \\
\text { remnant } 1 \\
(\mathrm{FR} 1)\end{array}$ & $\begin{array}{l}\text { Fragmented } \\
\text { remnant } 2 \\
(\mathrm{FR} 2)\end{array}$ & $\begin{array}{l}\text { Adjacent fragmented } \\
\text { remnant } 1 \\
(\mathrm{AFR} 1)\end{array}$ & $\begin{array}{l}\text { Adjacent fragmented } \\
\text { remnant } 2 \\
(\mathrm{AFR} 2)\end{array}$ & $\begin{array}{l}\text { Restored Site } 1 \\
\text { (RS1) }\end{array}$ & $\begin{array}{l}\text { Restored Site } 2 \\
(\mathrm{RS} 2)\end{array}$ & \\
\hline $\begin{array}{l}\text { Latitude, Longitude } \\
\text { Reproductive } \\
\text { attribute }\end{array}$ & $\begin{array}{l}3140 ’ 28 ” S \\
115 \text { 53’ 44’E }\end{array}$ & $\begin{array}{l}3149 ’ 09 ” S, \\
11552 \text { '29”E }\end{array}$ & $\begin{array}{l}3149 ’ 38 \text { 'S, } \\
11551 \text { ' } 311^{\prime \prime E}\end{array}$ & $\begin{array}{l}3144^{\prime} 07 ’ \mathrm{~S}, \\
11556 \text { '23”E }\end{array}$ & $\begin{array}{l}3206 ’ 18 ’ \mathrm{~S}, \\
11552 \text { '07'E }\end{array}$ & $\begin{array}{l}3147^{\prime} 09 \text { 'S, } \\
11556 \text { '32”E }\end{array}$ & $\begin{array}{l}3206{ }^{\prime} 288^{\prime} \mathrm{S}, \\
11552 \text { '01'E }\end{array}$ & \\
\hline $\begin{array}{l}\text { No. inflorescences } \\
\text { tree }^{-1}\end{array}$ & $9.2 \pm 1.4^{\mathrm{b}}$ & $5.9 \pm 1.3^{\mathrm{a}}$ & $10.4 \pm 1.2^{b}$ & $7.5 \pm 0.9^{\mathrm{ab}}$ & $8.8 \pm 1.5^{b}$ & $7.7 \pm 1.1^{\mathrm{ab}}$ & $21.7 \pm 0.8^{\mathrm{c}}$ & $<0.001$ \\
\hline No. follicles tree ${ }^{-1}$ & $31.6 \pm 8.4^{a b}$ & $38.6 \pm 15.1^{\mathrm{c}}$ & $36.1 \pm 7.7^{b c}$ & $59.9 \pm 16.3^{d}$ & $35.4 \pm 12.8^{a}$ & $52.9 \pm 16.7^{\mathrm{e}}$ & $99.9 \pm 16.7^{f}$ & $<0.001$ \\
\hline $\begin{array}{l}\text { No. of viable } \\
\text { seeds/follicle }\end{array}$ & $1.0 \pm 0.1$ & $1.2 \pm 0.2$ & $1.2 \pm 0.1$ & $0.9 \pm 0.1$ & $1.0 \pm 0.2$ & $1.1 \pm 0.1$ & $0.8 \pm 0.2$ & n.s. \\
\hline Viable seed set $(\%)$ & $75.5 \pm 5.6$ & $72.3 \pm 5.3$ & $76.7 \pm 6.0$ & $75.7 \pm 5.4$ & $70.1 \pm 0.8$ & $79.7 \pm 6.5$ & $80.8 \pm 2.9$ & n.s. \\
\hline Seed weight $(\mathrm{g})$ & 0.047 & 0.047 & 0.034 & 0.044 & 0.034 & 0.048 & 0.034 & n.s. \\
\hline
\end{tabular}


690 Table 2 Mating system, pollen gene pool, spatial genetic structure measures and simulation of paternity assignment (father given known mother)

691 at each site under strict (95\%) and relaxed (80\%) confidence levels for seven sites* of Banksia menziesii. Different lower-case letters indicate

692 statistically significant differences at $P=0.05$. *Population codes listed in Table 1.

\begin{tabular}{|c|c|c|c|c|c|c|c|c|c|c|c|c|c|c|}
\hline Parameter & \multicolumn{2}{|l|}{ LR } & \multicolumn{2}{|l|}{ FR1 } & \multicolumn{2}{|l|}{ FR2 } & \multicolumn{2}{|c|}{ AFR1 } & \multicolumn{2}{|l|}{ AFR2 } & \multicolumn{2}{|l|}{ RS1 } & \multicolumn{2}{|l|}{ RS2 } \\
\hline$N$ & \multicolumn{2}{|l|}{98} & \multicolumn{2}{|l|}{98} & \multicolumn{2}{|l|}{100} & \multicolumn{2}{|l|}{98} & \multicolumn{2}{|l|}{95} & \multicolumn{2}{|l|}{100} & \multicolumn{2}{|l|}{98} \\
\hline \multicolumn{15}{|l|}{ MLTR Mating system } \\
\hline Multilocus outcrossing rate $\left(t_{\mathrm{m}}\right)$ & \multicolumn{2}{|c|}{$1.09^{\mathrm{ab}}$} & \multicolumn{2}{|c|}{$0.98^{\mathrm{a}}$} & \multicolumn{2}{|c|}{$0.96^{\mathrm{a}}$} & \multicolumn{2}{|l|}{$1.20^{\mathrm{b}}$} & \multicolumn{2}{|l|}{$0.99^{\mathrm{a}}$} & \multicolumn{2}{|l|}{$1.20^{\mathrm{b}}$} & \multicolumn{2}{|c|}{$1.03^{\mathrm{a}}$} \\
\hline Singlelocus outcrossing rate $\left(t_{\mathrm{s}}\right)$ & \multicolumn{2}{|l|}{0.96} & \multicolumn{2}{|l|}{0.97} & \multicolumn{2}{|l|}{0.94} & \multicolumn{2}{|l|}{0.97} & \multicolumn{2}{|l|}{1.01} & \multicolumn{2}{|l|}{1.02} & \multicolumn{2}{|l|}{0.92} \\
\hline Biparental inbreeding $\left(t_{\mathrm{m}}-t_{\mathrm{s}}\right)$ & \multicolumn{2}{|c|}{$0.13^{\mathrm{abc}}$} & \multicolumn{2}{|c|}{$0.01^{\mathrm{ac}}$} & $0.02^{\mathrm{a}}$ & & $0.23^{\mathrm{b}}$ & & $-0.03^{\mathrm{a}}$ & & $0.19^{\mathrm{bc}}$ & & $0.11^{\mathrm{at}}$ & \\
\hline Correlated paternity $\left(r_{\mathrm{p}}\right)$ & 0.08 & & 0.15 & & 0.09 & & 0.16 & & 0.14 & & 0.13 & & 0.06 & \\
\hline Effective number of pollen donors $N_{e p}=(1 / \mathrm{rp})$ & 12.5 & & 6.5 & & 11.5 & & 6.3 & & 7.4 & & 7.9 & & 16.4 & \\
\hline Effective pollination neighbourhood area $A_{e p=} N_{e p} / d$ (ha) & 0.65 & & 0.06 & & 0.27 & & 0.33 & & 0.04 & & 0.09 & & 0.21 & \\
\hline TwoGener analysis & & & & & & & & & & & & & & \\
\hline Differentiation in pollen gene pool among families $\Phi_{F T}$ & 0.05 & & 0.07 & & 0.07 & & 0.09 & & 0.06 & & 0.08 & & 0.04 & \\
\hline Number of pollen donors $N_{e p}=\left(1 / 2 \Phi_{F T}\right)$ & 11.1 & & 7.3 & & 7.2 & & 5.7 & & 8.3 & & 6.2 & & 11.9 & \\
\hline Effective pollination neighbourhood area $A_{e p}=N_{e p} / d$ (ha) & 0.58 & & 0.06 & & 0.17 & & 0.30 & & 0.04 & & 0.07 & & 0.15 & \\
\hline $\begin{array}{l}\text { Estimated effective pollen area radius centred on each maternal } \\
\text { tree } A_{e p} \text { radius (m) }\end{array}$ & 26.96 & & 8.77 & & 14.58 & & 19.44 & & 69.96 & & 9.20 & & 13.63 & \\
\hline Maximum pollen dispersal distance $\delta(\mathrm{m})$ & 26.96 & & 8.77 & & 14.58 & & 19.44 & & 69.96 & & 9.20 & & 13.63 & \\
\hline Neighbourhood size $N b$ & 361 & & 285 & & 156 & & 144 & & 286 & & 401 & & undef & \\
\hline CERVUS & & & & & & & & & & & & & & \\
\hline Confidence $(\%)$ & 95 & 80 & 95 & 80 & 95 & 80 & 95 & 80 & 95 & 80 & 95 & 80 & 95 & 80 \\
\hline Critical LOD & 8.20 & 6.46 & 8.34 & 6.30 & 8.38 & 6.32 & 8.38 & 6.64 & 8.31 & 6.16 & 8.18 & 6.17 & 8.66 & 6.63 \\
\hline Observed assignment & 2 & 5 & 5 & 9 & 0 & 5 & 1 & 7 & 1 & 2 & 4 & 3 & 1 & 5 \\
\hline Assignment rate & $2 \%$ & $5 \%$ & $5 \%$ & $9 \%$ & & $5 \%$ & $1 \%$ & $7 \%$ & $1 \%$ & $2 \%$ & $4 \%$ & $3 \%$ & $1 \%$ & $5 \%$ \\
\hline Maximum pollen dispersal distance $P D D(\mathrm{~m})$ & 112 & & 1320 & & 1331 & & 210 & & 101 & & 212 & & 159 & \\
\hline
\end{tabular}




\section{$1 \quad$ Figure Legends}

2 Fig. 1 Location of study in Western Australia. a) the pre-European distribution (light grey)

3 and the likely current distribution of Banksia woodlands (dark grey). b) the old and new

4 populations sampled (in black) of Banksia menziesii for genetic diversity and mating system

5 parameters assessment of; Large non-fragmented remnant (LR), Adjacent fragmented

6 remnant 1 (AFR1) and Restored Site 1 (RS1), two fragmented remnants (FR1 and FR2)

7 within an urban landscape, and Adjacent fragmented remnant 2 (AFR2) and Restored Site 2

8 (RS2). Perth CBD is Perth Central Business District. Figure modified from ERIN,

9 Department of the Environment and Energy, Australian Government:

10 http://www.environment.gov.au/biodiversity/threatened/communities/pubs/131-indicative-

11 distribution-map.pdf

12

13 Fig. 2 Genetic diversity across adult (dark grey) and seed cohort (grey) cohorts $( \pm \mathrm{SE})$ for

14 heterozygosity (observed $\mathrm{Ho}$ and expected $\mathrm{He}$ ), inbreeding ( $F$; n.b., not calculated for

15 haploid offspring genotypes), average number of alleles ( $\mathrm{Na}$ ), effective number of alleles,

$16(\mathrm{Ne})$ private allele frequencies $(\mathrm{Pr})$ and allelic richness $(\mathrm{Ar})$. Different lower-case letters

17 indicate statistically significant differences at $P=0.05$.

19 Fig. 3 Population Graph representing both old (black) and new (white) sampling locations of

20 Banksia menziesii. The size of the nodes represent within population genetic variance and

21 connections reflect the topology of genetic covariance amongst all sampled populations.

22 Edges were classified based upon the physical separation of sampling locations and the expectation given genetic covariance under a model of isolation by graph distance. Normal

24 edges are shown in grey, extended edges (e.g., sample locations more spatially distant than expected by genetic covariance, indicating long-distance dispersal) are depicted with dashed 
1 lines, and compressed edges (e.g., sample locations in closer proximity than expected by

2 genetic covariance, short distance dispersal) are in dark bold lines. See Fig. 1 legend for 3 population abbreviations.

4

5 Fig. 4 Conditional genetic covariance among pollen pools for a) Large non-fragmented

6 remnant (LR), b) two fragmented remnants within an urban landscape (FR1 and FR2), c)

7 Adjacent fragmented remnant 1 (AFR1) and Restored Site 1 (RS1) and d) Adjacent

8 fragmented remnant 2 (AFR2) and Restored Site 2 (RS2), depicted as pollination graphs

9 overlaid on satellite images of sites. Nodes represent the population of pollen haplotypes

10 sampled by each maternal family. Edges represent significant statistical covariance among

11 pollen pools. Colour version of this figure available online. 


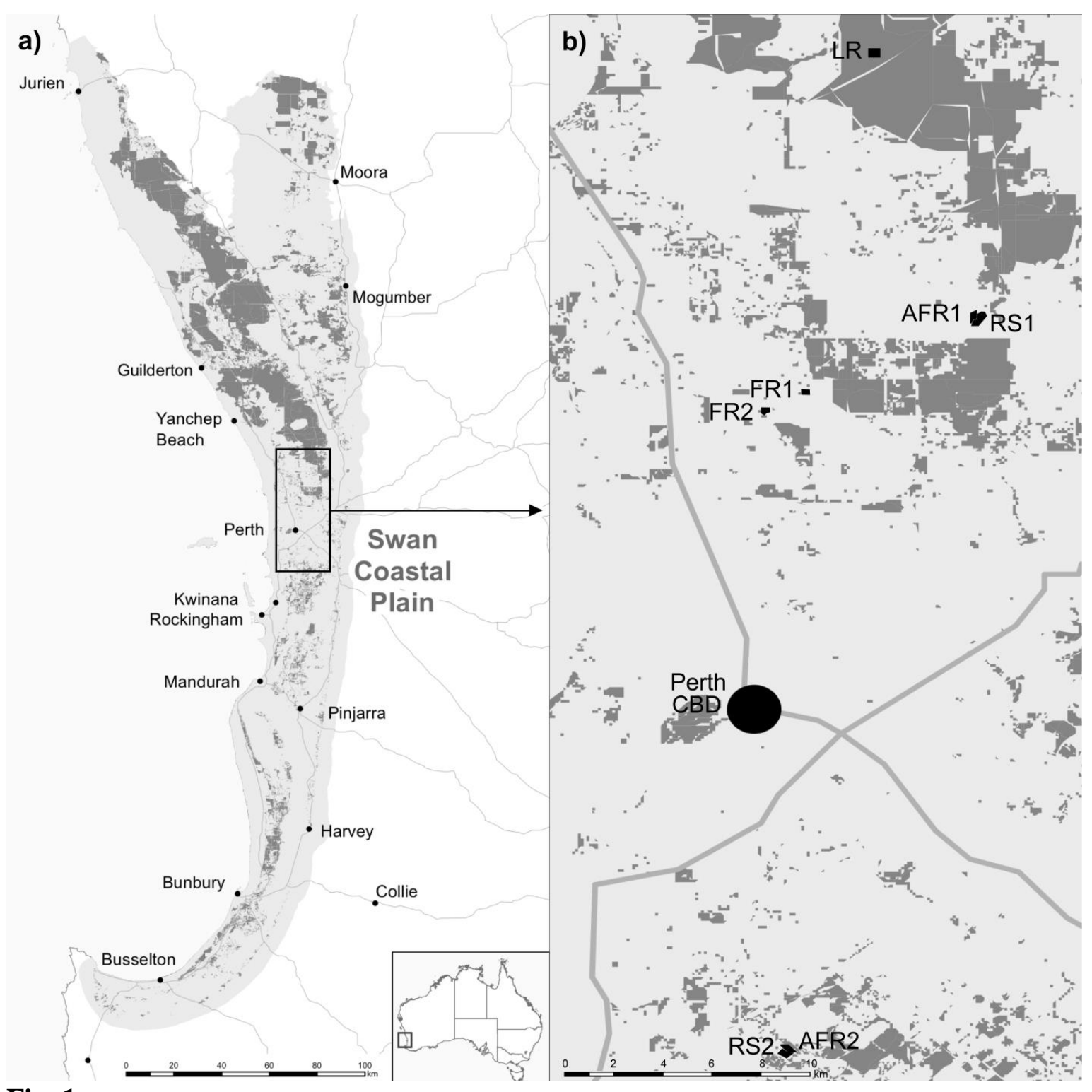

Fig. 1 


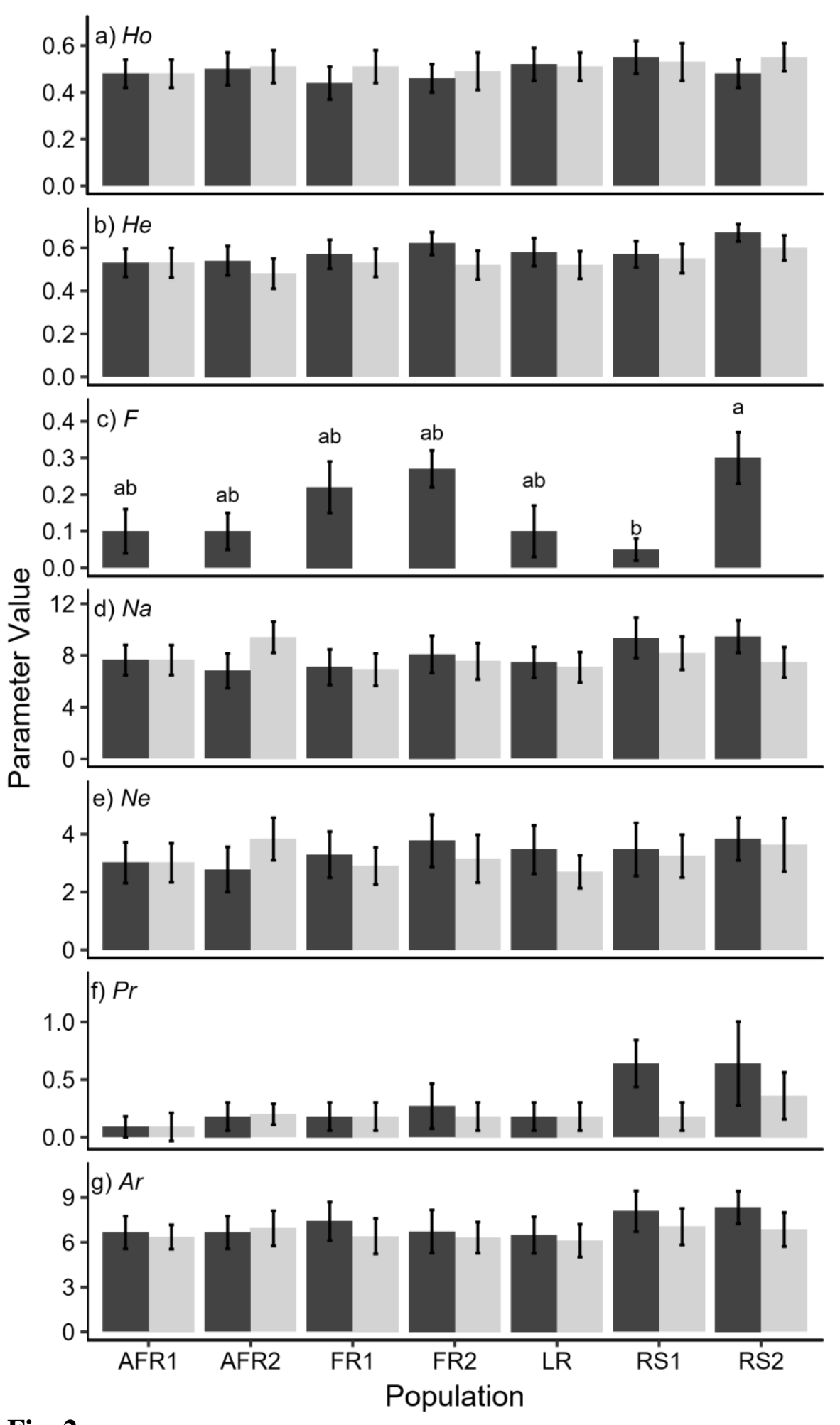

Fig. 2 


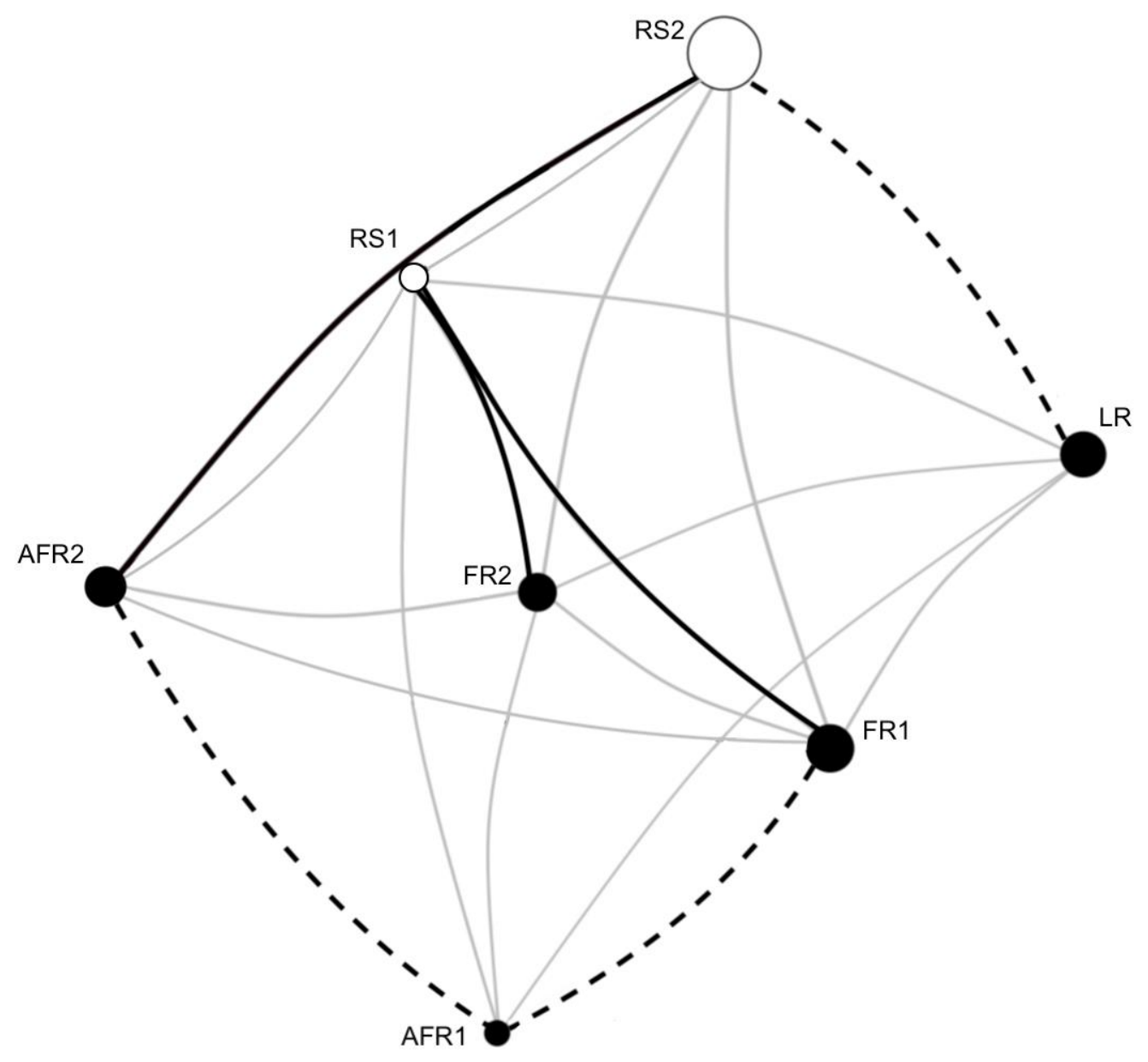

Fig. 3 

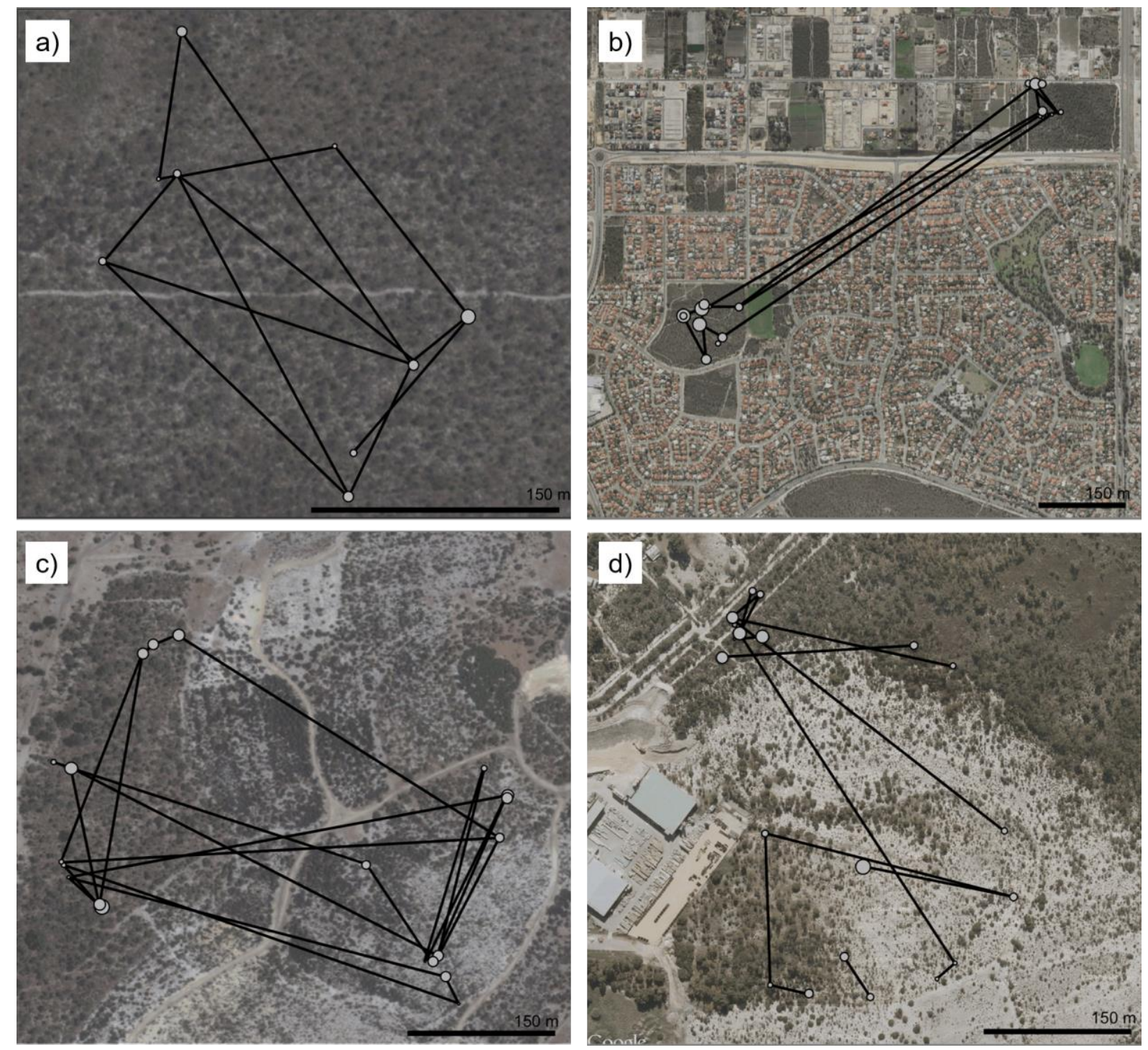

Fig. 4 


\section{Click here to access/download \\ Supplementary Material ESM information.docx}

